\title{
DISCRETION OF INSTITUTIONS
}

The article considers discretion enjoyed by institutions. Discretion enjoyed by institutions implies that law grants a right to choose between various legal implications for the person who applies the law. Discretion is a legislative tool which helps achieve a high level of fairness in an individual case. Discretion of institutions provided by lawmakers enables an institution to consider the specific circumstances of a specific situation and reach a fairer result. However, even such "freedom" imposes an obligation on the institution to apply it in a responsible and correct manner. Discretion does not mean that the institution is granted absolute "freedom" or arbitrariness. The scope of control of discretion in a higher institution and a court differs. A higher institution independently carries out all feasibility assessments for a second time based on merit, ultimately reaching a similar or different result. The courts can verify the validity of the activities undertaken by the public administration: a) failure to use discretion; b) abuse of discretion; c) misuse of discretion. The courts do not have the right to take a decision on the most appropriate result since it leads to violation of the principle of separation of powers.

Key words: administrative proceedings, discretion of institution, discretionary powers, types of discretion of institution. 


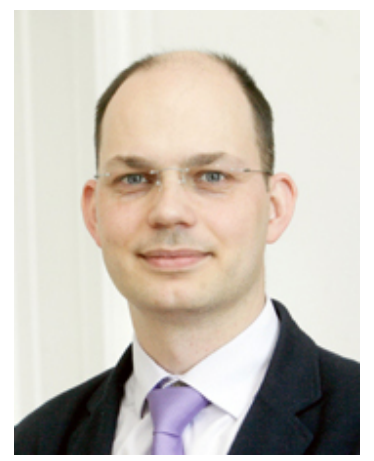

Janis Neimanis, Associate Professor at the Faculty of Law of the University of Latvia, Judge of the Supreme Court of Latvia

\section{Introduction}

It is believed to be a rule that a sanction for a criminal act is determined by the criminal law in some frameworks providing an enforcer with an opportunity to individualize a criminal penalty. Whereas, according to civil law, parties to the contract are entities which create the own model of actions within law, for example, the determination of place, time and method of contract performance, including the number of funds to strengthen the obligations (e. g. the amount of the penalty).

Administrative law also should stipulate a method for the establishment of legal relations between an institution and an individual comparing the legal effects and circumstances of a single case, that is, the method of how the institution can act more elastically in executing orders of public administration. Thus, when issuing a law, the legislator usually evaluates whether it should provide an institution with the discretion of the definition of legal effects in the process of resolving some issues and what discretion limits should be. The legislator can deny granting discretion to the institution as well if it believes that some situations should be solved in the way prescribed by law. Such concerns may be based on the political stance of the legislator, the way of how public administration tasks should be carried out and what specific output the institution has to achieve.

Discretion of the institution granted by the legislator is a task for the very institution because to use discretion adequately, it is important: 1) to identify it; 2) to define its limits correctly; 3 ) to specify legal effects in a single case in the right manner.

\section{Definition of discretion}

Applying the right in the institution or the court, one should clarify whether the right grants the institution's discretion. For this reason, law executor should find out or interpret the content of a relevant legal rule. Namely, whether the legal rule uses a standard form of obligatory effects - the present tense verb in the indicative mood in the third person - as a rule, this is evidenced by the wording of the legal rule, e. $\mathrm{g}$. it "supersedes", "issues", "concludes". Thus, the discretion granted to the institution is identified if the text involves a permissible verb, e. g. "can issue", "be entitled", "can", "be permissible" etc.

Law doesn't always use that sort of terminology which directly makes it clear whether the institution enjoys discretion. Consequently, the determination of discretion based on the legal 
terminology may be erroneous because the conclusion on discretion is made relying on the scope of a legal rule, i. e. discretion is found out not only textually but also through the use of other arguments for law interpretation - history, system or goal.

For example, Article 20 of the Law on the Penitentiary Department includes two legal rules whose wordings differ contextually. The first part stipulates the discretion of the institution directly within the text:

(1) An official can be in office until the age of fifty. The term of office may be extended at the will of the official under authority of written consent of the direct superior and decision of a personnel review commission of the relevant institution:

1) for Head of the Department and his deputies, Chief of the institution and his deputies - upon a decision of the Minister of Justice;

2) for other junior and senior officers - upon a decision of Head of the Department;

3) for non-management employees - upon a decision of Chief of the institution.

The second part of the text doesn't directly specify whether the legislator has granted the institution discretion. For example, sub-item " $\mathrm{j}$ " of the provision of law marks as follows:

(2) Official relations are terminated:

1) if an official is relieved from office:

$<\ldots>$

j) the official hasn't been exercising professional duties for more than four months (120 days) in a row due to the temporary disability.

The administrative court heard a dispute towards the application of sub-item " $\mathrm{j}$ " because the institution believed that this provision stipulates the issuance of obligatory decision (without discretion of the institution). The Supreme Court held that the institution was provided with discretion .

The court indicated that despite the use of a standard form of obligatory effects "official relations are terminated" in the legal provision, it is out of the case creating the effects - a decision on relief of the official. The verb "to relieve" is formulated in such a way that law executor can't make a direct pronouncement on the authority to issue obligatory administrative act. According to the results of a study of the external system of legal provisions and aim of the law, one can note the legislator independently assesses that temporary disability within three months is quite long for the statement of violation of stable and effective activity of public administration and concludes about the expediency. In each particular case, the legislator leaves the assessment of whether and when the long-time temporary incapacity for work of a certain official hinders a stable and efficient activity of the public administration to the discretion of the institution. When interpreting the law, one can reach different results - all of which meets the legal system and the court favors the interpretation results which assist to the achievement of the most reasonable and fair outcome for every individual case. In deciding which result will be more efficient, the court takes into account the reality of public life, i.e. the Penitentiary Department has a lack of human recourses as well as the influence of employees' ageing on the fulfillment of the functions of public administration. It is also taken into consideration the fact that state regularly trains officials and invests public funds in their professional development. Consequently, the court considers the interpretation result 
which allows the institution to decide independently on the individual need, effectiveness and commensuration due to the influence of long-term incapacity to work on the stable and efficient fulfillment of the official duties as the most expedient.

\section{Separation of discretion from the freedom of assessment}

The discretion granted to the institution is always stipulated in the context of the legal effects of the legal provision. The above permits separating it from the freedom of assessment, which is stipulated in the part of legal composition (preconditions) of the legal provision.

For example, the law establishes that an official may be transferred to another post due to the lack of the respective office holder or another vacant post, taking into account requirements for the relevant post, for work-related interests for a certain time to secure an effective exercise of professional duties.

"For work-related interests" provides the institution with the freedom of assessment that is the right to assess whether they exist and how best to achieve them. Indeed, "can be transferred for a certain time" gives the institution discretion.

Such a differentiation is necessary because the scope of control differs. Thus, the court can't be against the assessment of the institution while the use of discretion may be partially controlled by the court. The Supreme Court was due to reverse a judgment of the court of inferior jurisdiction in which it fundamentally verified whether "workrelated interests" were defined correctly.

\section{Types of discretion}

Law has two types of discretion, which are differentiated between each other when there are the questions:

1) shall one take actions?

2) how to act?

The first case refers to the discretion of the institution towards deciding on the participation in the actual situation through its decision, and the second - the choice of legal effects. In the first case, it calls an administrative act of the choice of issuing and in the second - administrative act of content choice.

For example, the law establishes that an official can be employed until the age of fifteen. Taking into account the work-related need, physical and professional capacities, as well as the health condition of the officer, head of the institution, is empowered to extend the term of tenure of employment no more than until the age of sixty.

It follows that law gives discretion for making a choice:

a) to take actions - "to extend the term of tenure of employment";

b) the way of actions - "to extend the term of tenure of employment no more than until the age of sixty".

There may be also a situation in which the legislator empowers the institution to make a free choice, whether it is necessary to take actions and how to act, or empowers the institution to issue free administrative act.

\section{The most common mistakes of the institutions when using discretion}

Considering judicature of the Supreme Court in the framework of the issue concerned, one states that usually, institutions make mistakes when using discretion if:

1) they are not familiar with discretion described in the legal provision by the legislator, and they don't use it believing that provision needs issuing of an obligatory decision in 
the specific case whose content is directly specified in the law. For example, the Law "On Taxes and Dues" fixes that "taxpayers, except individuals, declare all dealings for cash on a reciprocal basis during a month as provided by the Cabinet of Ministers (despite the fact whether the deal was in the context of one operation or several operations) and the amount of which exceeds 1000 lat. If the deals for cash, the amount of which exceeds 1000 lat, are not declared, one shall pay fine in the amount of 5 per cent of the total amount of the undeclared dealings. The State Revenue Service has imposed a fine in the amount prescribed by the law, but the general provision mentioned in the same law is not observed. The provision states that when assessing the essence and nature of the violation of a taxpayer, the frequency of violation, damage suffered, fidelity of taxpayer, tax administration is entitled to reduce a fine imposed in the result of the control measures (tax audit and revision) by $70 \%$ if the taxpayer challenges a decision of tax administration;

2) in the framework of discretion, it is concluded inappropriately about a reasonable nature of the decision: necessity and applicability in the case of an unfavourable decisionneed and correspondence. It refers to the cases when the institution uses the conclusions, which are inadequate for the facts of the case (outside the case context) or when it takes disproportionate actions. For example, the law establishes that an official can be fired due to the post retrenchment if the institution doesn't have another post which could be proposed to the official. The institution has dissolved the post of spokesperson and officially proposed the official the post of custodial supervisor. The court declared that sort of discretion use disproportionate as it was not taken into account that the official is not qualified for the performance of such a work.

It should be pointed out that court is not entitled to make decisions about the most effective result as in such a way, the principle of division of powers is violated. For this very reason, the court gives up indicating the specific result.

Nevertheless, the court recognizes the fact that a private individual has the right to require the institution uses its discretion accurately. The court can verify the eligibility of action of the public administration when using discretion. Discretion of the public administration is not used legally if it is invalid. Consequently, the court should revise the possible mistakes in using discretion: non-use of discretion, abuse of discretion, misuse of discretion. Discretion of public administration is misused if its use contravenes the rules regulating a proper use of discretion - if a decision-maker doesn't give a general assessment methodically correct and doesn't adhere to the specific legal provisions, the principle of prohibition or the principle of procedural honesty.

For example, the court admits the institution has put discretion to good use within permitted limits and revoked the gun license of a private individual threatening to murder his wife. Evaluating expedience, including interests of public safety, there is a risk that private individual may maliciously use the weapon .

\section{Reduction of discretion to the only option}

As it was mentioned above, the discretion of the institutions indicates that legal provisions provide the institution with the freedom of action choice. In a separate case, the choice can be reduced to the only option, or as German literature defines - the reduction of discretion to zero. It is expressed in such a way that one-and-only decision is an error-free decision, and the choice of other choices is wrong. 
For example, the court states that according to the legal provisions, a head of the municipal kindergarten is authorized to decide that a child is registered for entering the establishment out of turn. In practice, the head used the rights in such a way that if a sibling already visits the kindergarten, it is accepted his/her sibling. In the specific case, the head of the kindergarten refused to accept the child out of turn. The court marked, based on the principle of legal equality, this principle should be applied to all children, and discretion is reduced to zero in this case untill the institution doesn't change its practice generally.

\title{
7. Conclusions
}

Latvian Administrative Procedural Law has been applying in the modern sense since 2004. During that period, an administrative court completely joined dogmatics of German law in terms of administrative procedural law, including the discretion of institutions. Over 10 years, the national judicature also formed.

Discretion of the institutions granted by the legislator permits the institution to take into account the circumstances of an individual situation and come to the most reasonable result. Nevertheless, even such "freedom" binds the institution to use it responsibly and error-free. Discretion doesn't mean the institution has an absolute "freedom" or abuse of discretion.

Typically, the institution doesn't consider the fact that it is provided with discretion through legal provisions, or it misuses discretion by making an inadequate conclusion or ignoring the balance when defining the legal effects.

\section{СВОБОДА ДІЙ УСТАНОВИ}

\author{
Яніс Нейманіс, \\ доцент юридичного факультету \\ Латвійського університету, \\ суддя Верховного суду Латвії
}

\begin{abstract}
У статті розглядається свобода дій установи. Свобода дій установи означає, що закон надає особі, яка його застосовує, право вибору різних правових наслідків. Свобода дій є законодавчим засобом, завдяки застосуванню якого досягається більш високий рівень справедливості в індивідуальному випадку. Свобода дій установи, яка надається законодавием, дає можсливість установі враховувати обставини індивідуальної ситуаиії та досягати найбільш справедливого результату. Проте навіть така «свобода» накладає на установу обов'язок відповідально й безпомилково ї̈ використовувати. Свобода дій не має на увазі, щяо установі надано абсолютну свободу чи свавілля. Обсяг контролю свободи дій у вищому закладі та в суді є різним. Вища установа самостійно виконує всі оиінки доиільності по суті повторно, у підсумку досягаючи аналогічного або іншого результату. Суд може перевірити правомірність діяльності держсавного управління, зокрема: а) невикористання свободи дій; б) перевищення свободи дій; в) неправильне використання свободи дій. Суд не має права приймати рішення про найбільи доичільний результат, адже таким чином буде порущений принцип поділу влади.
\end{abstract}

Ключові слова: адміністративний процес, свобода дій установи, дискреційні повноваження, види свободи дій установи. 